\title{
Short-term Expectations in Listed Firms: The Effects of Different Owner Types
}

\author{
Tor Brunzell, Eva Liljeblom and Mika Vaihekoski
}

25.8.2012

\begin{abstract}
We report empirical evidence regarding the disciplining role of different institutional and other owners in reducing managerial myopia. Using data from a large Nordic survey, we find that companies to a reasonably high degree feel that external pressure for a good result in the short-term generates conflict with the company's long-term goals. We test for the effect of several ownership types, and find that especially in firms with a large private equity owner the perceived pressure for short-term actions is reduced. In addition, we find a negative association between firm profitability and short-term pressure. We also find support for a behavioral characteristic: younger managers feel significantly more pressure. Firms subject to higher pressure undertake more actions to accommodate that pressure. Again, the impact of especially a large private equity owner is beneficial because such firms undertake significantly less often actions that are likely to destroy value, such as deprioritizing their long-term investments or R\&D.
\end{abstract}

\footnotetext{
In alphabetical order. Brunzell: Stockholm University, School of Business. E-mail: tb(at)fek.su.se. Liljeblom: Hanken School of Economics, Department of Finance and Statistics. E-mail: eva.liljeblom(at)hanken.fi. Vaihekoski: Turku School of Economics, Department of Accounting and Finance and Lappeenranta University of Technology, School of Business. E-mail: mika.vaihekoski(at)lut.fi. We are grateful for comments obtained at the 10th Workshop on Corporate Governance and Investment at the CBS. Authors wish to thank Nils Liljendahl, Kirsi Noro, Magnus Blomkvist, and Anna Björn for research assistance. Financial support from NASDAQ OMX Nordiska Stiftelse för främjande av vetenskaplig forskning på värdepappersområdet and Academy of Finland is gratefully acknowledged.
} 
Key words: finance, short-term behavior, myopia, owner types, private equity, underinvestment

JEL Classification: G31, G34, L21, M51, M52

\section{$1 \quad$ INTRODUCTION}

A number of studies have reported evidence of various corporate actions that do not serve the long-term interests of the company or its shareholders (see, e.g., Klein, 2002; Brockman, Khurana, and Martin, 2008; Bushee, 1998 and 2001; Chakravarty and Grewal, 2011). These actions include, among others, earnings manipulation, unnecessary cost cutting, or underinvestment. ${ }^{1}$ One explanation offered for corporate myopia, or short-termism, is a short-term focus of the management. This managerial short-termism would stem from an unsolved agency problem between long-term shareholders and a more short-term management. Compensation systems with a short-term focus or short employment horizons, combined with weak corporate governance, have been suggested as the main drivers of such myopia (for empirical support, see, e.g., Marquardt, Tan, and Young, 2009).

However, short-termism may also be driven by the short time horizons of the owners rather than the managers. ${ }^{2}$ The effects of ownership on managerial myopia have been studied both by looking at ownership concentration ${ }^{3}$ and ownership type ${ }^{4}$ (using, e.g., categories such as "institutional" or "transient" owners). The empirical evidence, however, remains rather mixed. Institutional ownership has been found to bring both advantages in terms of

${ }^{1}$ For example, Graham, Harvey, and Rajgobal (2006) find in their survey of senior financial executives in the U.S. that managers seem to be willing to undertake short-term actions which may be value destroying (such as reducing $R \& D$, advertisement, maintenance, and delaying the start of a new project) in order to meet performance targets.

${ }^{2}$ Several papers suggest that different owners may have different investment horizons and focus. E.g. Bushee (1998 and 2001) indicate that the influence of institutional investors with a short-term focus may encourage managers to sacrifice long-term investments such as R\&D to meet current earnings targets, or overweight near-term expected earnings. Koh and Hsu (2005) find support for the co-existence of both transient and long-term oriented institutions, with different views on earnings management. Suto and Toshino (2005) find a short-term bias in fund managers' investment time horizons.

${ }^{3}$ E.g. Baysinger, Kosnik, and Turk (1991) find support for the positive influence of ownership concentration, e.g., on R\&D strategy and firm level diversification.

${ }^{4}$ See e.g. Graves (1988), Baysinger et al. (1991), Hansen and Hill (1991), Zahra (1996), Lee and O'Neill (2003), and Liljeblom and Vaihekoski (2009). 
corporate governance and monitoring ability (see e.g. Lee, 2005), as well as disadvantages through their frequent trading and the short-term compensation systems for institutional fund managers. Institutional investors also typically face severe diversification rules and other barriers for shareholder activism, limiting their role as active investors in individual firms (David and Kochhar, 1996; Edwards and Hubbard, 2000). The category of institutional owners is also a mixed one, including both e.g. public pension funds often associated with a long-term focus, as well as investment funds and mutual funds, typically associated with a short time horizon (see e.g. the results by Hoskisson, Hitt, Johnson, and Grossman, 2002; Zouari and Rebai, 2009, concerning their differenteffects on innovation strategies and earnings manipulation, respectively). Most studies have also used data pertaining to the U.S., where wide ownership dispersion and the dominance of institutional owners may make it difficult to find cross-sectional differences between firms.

Our paper contributes to the earlier literature in several ways. First, we add to the earlier literature on the effects of different owner types on managerial myopia using data from all the Nordic countries. Our study relates to papers which address heterogeneity among owners and owner types, such as Fiss and Zajac (2004), and Cronqvist and Fahlenbrach (2009). The Nordic countries offer a very suitable environment for the study of the effects of large owners and owner types on myopia for a number of reasons. First, there is a large variation in ownership concentration as well as owner types between firms that are listed on the Nordic markets, ranging from large firms with multiple international listings and a dispersed ownership structure, to firms controlled by very large individual owners (such as private investors, financial institutions, industrial firms as well as a state or a municipality). Such large cross-sectional differences in ownership concentration and type make it easier to isolate potential differences in ownership effects on myopia. Second, most Nordic firms have corporate boards that are dominated by external board members, typically including those representing the large owners. In that way, the voice of the large owner types is more likely to be heard already through board work rather than through the threat of exit. 
In addition, we use a more detailed categorization of owner types than the ones used in the literature earlier, including a detailed analysis of various different institutional owner types including, as a novelty in this setting, private equity owners. Moreover, we directly study the short-term pressure felt by the management using survey data, and we furthermore contribute by studying the pressure felt by three different corporate executives/directors: the chairman of the board, the CEO, and the CFO. A study of their potentially differing roles in this respect has not been conducted earlier. Finally, instead of looking at one specific corporate action that may be affected by managerial myopia, we study the effect of shortterm pressure felt on a multitude of different actions, again using survey data. ${ }^{5}$

We find that the pressure for short-term behavior is significantly reduced by the presence of private equity owner. Somewhat surprisingly, some large owner categories such as private owners are not able to reduce pressure for short-term actions. Firms subject to greater pressure also seem to undertake more actions to accommodate short-term pressure. We also find that the firms' profitability is negatively affected by the presence of the short-term pressure.

Our study combines three sources of data: (1) unique survey data on the perceived pressure for short-term decisions, its origins, and corporate reactions to it, (2) financial data on the actual characteristics and performance of firms, and (3) data on the largest owners and their type. Our survey data is based on responses to a questionnaire directed to the Chairmen, CEOs, and CFOs of all the companies listed on five Nordic stock exchanges (Denmark, Finland, Iceland, Norway, and Sweden) in 2007 and early 2008.

The remainder of this paper proceeds as follows. In section 2, we discuss the related literature in more detail and develop testable hypotheses. In section 3, the research design

\footnotetext{
${ }^{5}$ This part of our paper relates to Grahan, Harvey, and Rajgopal (2006) in the sense that we also study survey data on value destroying actions, with the difference that we relate our findings to different large shareholder types.
} 
and methodology is presented. In section 4, we present the main empirical results together with a discussion of their implications. The final section presents our conclusions and offers some suggestions for further research. 
The concept of short-termism or managerial myopia refers to an excess orientation towards short-term profits so that even decisions that compromise the long-term goals of the firm may be made. We will start by discussing the impact of large owners and owner types on the degree of short-term pressure felt. Next, we will discuss the potential consequences of short-term pressure, in terms of actions taken by the firm.

\subsection{The impact of ownership and owner types}

Theoretically, if agency problems can be avoided (e.g., alleviated through corporate governance mechanisms), the incentives of managers should be aligned with those of the owners. However, weak corporate governance, together with short-term incentives for the managers, can lead to agency problems and manager myopia. Myopia may for example lead to earnings manipulation, an unwillingness to invest (for instance, in R\&D), and the use of discount rates or payback rules which are too demanding.

Even without agency problems, myopic behavior can occur at the firm level because of managers acting in the interest of owners who have a short-term focus. Next, we will analyse evidence on owner horizons associated with different owner types, starting first with large institutional (financial) owners and then continuing with other large investors.

\section{Large institutional owners}

Prior empirical research on the relationship between corporate ownership and managerial myopia has mainly studied the influence of large owners in general, or some specific owner types, on some individual corporate action where myopic decision making may be manifested in. Especially the role of institutional investors has been in focus (see Gillian and Starks, 2003, for a survey of the role of institutional investors in corporate governance). As large shareholders, institutional investors can have greater incentives to be active owners and monitor the management (Shleifer and Vishny, 1997). Evidence supporting the myopia 
reducing role of institutional owners in the connection with $R \& D$ investments have been reported e.g. by Baysinger et al. (1991), Hansen and Hill (1991) ${ }^{6}$, and Zahra (1996), while contradictory results (a detrimental effect on R\&D investments) have been reported e.g. by Graves (1988), and in the survey by Graham et al. (2006), where managers pointed out institutional investors as the main category of shareholders causing short-term behavior. ${ }^{7}$

However, the group of institutional investors is a heterogeneous shareholder class, including both transient and more long-term owners. ${ }^{8}$ Many institutional investors such as mutual fund managers face short-term compensation schemes tied to recent fund performance, and are involved in active trading, elements which can make their focus rather short-term, such as on returns from daily up to a yearly level. They also face severe diversification rules, limiting their role as large investors in individual firms (for an analysis of the barriers to shareholder activism faced by many institutional investors, see e.g. David and Kochhar, 1996; Edwards and Hubbard, 2000; David, Hitt, and Gimeno, 2001; Gillian and Starks, 2003). On the other hand, the group includes also more long-term owners such as pension funds, venture capitalists, and banks, which are more likely to be active investors and influence firms' decisions (Kochhar and David, 1996; David et al., 2001). Positive effects on R\&D spending or new product announcements have been found e.g. by Kochhar and David (1996), Bushee (2001) and David et al. (2001), after controlling for the type of the institutional owner (pressure-resistant investors / less transient investors / investors involved in shareholder activism).

Support for the heterogeneity of institutions has also been found in a number of studies on other types of actions. E.g. Koh (2003) as well as Burns et al. (2010) found that ownership by more transient institutions is positively related with earnings management / the likelihood and magnitude of financial restatements, supporting the perception that some institutions

\footnotetext{
${ }^{6}$ Hansen and Hill (1991) focus on institutional investors and contrast the myopic institutions theory (advanced e.g. by Drucker, 1986, and Graves, 1988) with the efficient market theory, and find support for the latter. When looking at the determinants for R\&D investments, they find support for the view that higher levels of institutional ownership may be associated with greater R\&D expenditure.

${ }^{7}$ When interviewing managers, they referred to the compensation of fund managers as a cause for short-term focus.

${ }^{8}$ See e.g. Bushee (1998), who developed a method to classify institutional investors into shorter and longerterm investors based on the characteristics of their portfolio, such as its concentration and turnover, and the trading sensitivity to current earnings. Investor types may also vary across countries. See also Cronqvist and Falhlenbrach (2009), who find that U.S. blockholders in general are highly heterogeneous.
} 
are myopic. The results of Chen et al. (2007) support the hypothesis that only independent institutions with long-term investments will specialize in monitoring the firm, in which case their holdings are related to post-merger performance.

Institutional owners include banks, insurance companies, private and public pension funds, investment companies, mutual funds as well as activist funds. Only a few studies have looked in more detail at how specific owner types among the category of institutional owners influence corporate myopia. By studying pressure-resistant investors (their positive effects on R\&D), Kochhar and David (1996) look at the groups of public pension funds, mutual funds, and endowments and foundations owning at least $1 \%$ of equity and find positive effects on R\&D spending. Zouari and Rebai (2009) study the effect of institutional ownership on accruals management, and find that while the involvement of pension funds and banks limit earnings management behavior, investment fund ownership is associated with increases. Hoskisson et al. (2002) look at innovation strategies, and report that public pension funds prefer internal innovation (R\&D investments, and new product innovations) whereas professional investment funds prefer external innovation (acquisitions), probably because the latter ones result in more immediate changes in the firm's market value. They relate these results to the differences in the owners' time horizons and incentives.

In studies of the effects of institutional investors on corporate political strategies and shareholder orientation, ownership types such as banks, insurance companies, firms, government, and family have been studied. Ozer, Alakent, and Ahsan (2010) found that ownership by banks and insurance companies reduce investment in corporate political strategies. Fiss and Zajac (2004) in turn found that higher ownership by several ownership types which have espoused a shareholder value orientation influences the firm's shareholder value orientation. Brav et al (2008) find that hedge fund activism is consistent with an overall improved performance at target firms, and also argue that (contrary to what some critics have claimed), hedge fund activists are not short-term in focus. ${ }^{9}$

'See also e.g. Clifford (2007), who found evidence on improvements in operating performance (ROA) in firms targeted by hedge funds with active investment intentions. In a clinicalstudy of the Hermes fund, Becht et al. (2009) report that the fund executes shareholder activism predominantly through private interventions unobserved in a study of public information, and substantially outperforms its benchmarks. However, 
We study the effect of various types of large financial institutional owners (INST) on the pressure for short-term actions faced by the management. We define a large owner as one who owns at least $20 \%$ of the equity in the firm. ${ }^{10}$ Our subgroups of large financial institutional owners include first of all banks, public pension funds, and insurance companies as a joint group (BANK_PENS_INS), since these owners are typically perceived as more longterm ones with a good monitoring capacity. Secondly, we study investment companies and mutual funds (FUND), jointly, since both are typically perceives as short-term oriented, and since it is hard to draw the line between them when classifying especially foreign owners. Finally, we include active owners (mainly private equity funds and venture capitalists, but also some hedge funds) (ACTIVIST), and endowments (ENDOWM) as the last two categories.

We expect that the pressure for short-term actions is smaller in firms with longer investment horizons, i.e. among BANK_PENS_INS and ENDOWM as compared to FUND. Based on the results of e.g. David et al. (2001) for active investors, as well as the results from the financial activists literature (see e.g. Clifford, 2007; Brav et al., 2008; Mietzner, Schweizer, and Tyrell, 2008; Klein and Zur, 2009), we also expect that activists such as private equity investors, venture capitalists, and hedge funds may, as probably our most active "institutional" investors, help in reducing pressure for short-term actions. ${ }^{11}$ As a result we specify the following hypothesis.

Greenwood and Schor (2009) study the positive announcement effects on activist purchases, and show that these returns are largely explained by the ability of activists to force firms into takeovers

${ }^{10} \mathrm{~A}$ cut-off point of $20 \%$ may seem large from e.g. a US point of view, where $5 \%$ or $10 \%$ have often been used as a rule, but it is not so for Nordic firms where ownership is typically highly concentrated. In our Nordic sample, $54.5 \%$ of the firms have a blockholder holding at least $20 \%$ of the stock, and the largest owner holds on average $26.1 \%$ of the stocks. Robustness tests reveal that differences between owner type effects are discernible only for reasonably large ownership levels, i.e. it takes a larger ownership stake to be able to influence corporate policy, as could be expected.

${ }^{11}$ Evidence on activists which may be interpreted somewhat differently is given e.g. by Bethel, Liebeskind and Opler (1998), and Greenwood and Schor (2009). Both find that activist purchases result in some form of reduction in investments (increases in asset divestitures, or reduction in capital expenditures). 
Hypothesis 1: The pressure for short-term behavior is lower than average in firms where a large, long-term / active institutional investor (BANK_PENS_INS, ENDOWM, or ACTIVIST) is present.

\section{Other large owners}

Also other than institutional (financial) large owners may reduce myopia. ${ }^{12}$ In a recent paper, Edmans (2009) suggests that blockholder presence could reduce managerial myopia because blockholder trading can make the stock price more informative (reflecting fundamental value rather than short-term profits). Another prediction is that blockholders are particularly valuable in promoting unobservable investment. This prediction is supported e.g. by Baysinger et al. (1991) and Lee and O'Neill (2003), who find a positive relationship between ownership concentration and R\&D investment. Cronqvist and Falhlenbrach (2009) in turn find that although U.S. blockholders are highly heterogeneous, the appearance of certain types of blockholders is associated with later increases in investment. Edmans (2009) interprets this finding as supportive to the idea that a blockholder allows the manager to pursue investment projects that he has earlier avoided out of fear of interim turbulence (i.e., a large long-term owner could reduce managerial short-termism). Support for a positive relationship between non-financial corporate block ownership and R\&D investments was also obtained by Tribo et al. (2007) using Spanish data.

While these papers have mainly focused on the relationship between blockholders and investment, other effects arising from the presence of a large blockholder have also been reported. For example, the results of Klein (2002), Becker et al. (2011), and Brockman and Yan (2009) indicate that large shareholders / a large and active blockholder can have an effect on, e.g., reducing earnings manipulation, increasing the profitability of the firm,

\footnotetext{
${ }^{12}$ The empirical evidence on the various effects of a large owner has historically been rather mixed. Holderness (2003) concludes in his survey of blockholders and corporate control that surprisingly few corporate decisions have been shown to be different in the presence of a blockholder, and that ownership concentration appears to have little impact on firm value. Themore recent evidence, e.g., by Becker et al. (2011) and Brockman and Yan (2009) contradicts this view. Cronqvist and Fahlenbrach (2009) in turn show that blockholders do have significant fixed effects on firm policies, but that they are very heterogeneous.
} 
reducing executive compensation, and shaping the firm's information environment. Transient owners in turn can lead to actions targeted to short-term value creation, see e.g., by Bushee (1998), Chen et al. (2007), and Burns et al. (2010).

Very few papers have studied the effects of specific blockholder types (other than institutional investors) on short-term actions. Fiss and Zajac (2004) found that higher ownership by several ownership types which had adopted shareholder value orientation influenced the firm's orientation. These groups included, besides institutional owners, private owners and other firms as owners. Liljeblom and Vaihekoski (2009) find that in a sample of large, mainly unlisted firms, the pressure for short-term actions was smaller in firms categorized as owned by a more long-term owner (a private owner, the state ${ }^{13}$ or a municipality, or a co-operative) as compared to listed firms, firms owned by private equity owners, foreign owners, as well as firms owned by another firm.

We will study blockholders, owning at least $20 \%$ of the equity, from the following categories: state or municipality (STATE_MUN), a private owner (PRIVATE), a co-operative (CO_OP), and a non-financial firm (FIRM). Our expectation is that also a large blockholder other than an institutional owner might mitigate the pressure for short-term actions, but perhaps not by as much as an institutional owner (a financial institution or like) with better monitoring capability, and most likely better possibilities to finance the company. As typically well diversified owners, institutional owners may also be less sensitive to short-term swings in the profitability of the firm, as compared to e.g. many private owners as well as cooperatives who may be mostly relying on income from an individual firm.

\footnotetext{
${ }^{13}$ Note that in the Nordic countries, the state is typically considered a long-term investor contrary to the USA where the long-term government ownership is frown upon (cf. General Motors).
} 
Hypothesis 2: The pressure for short-term behavior is lower in firms where a large nonfinancial investor is present, but not as reduced as in the case of a long-term financial institutional owner.

\subsection{Corporate actions undertaken in response to short-term pressure}

Next, we turn to corporate actions that may be caused by pressure to achieve good results in the short-term. Several studies have reported evidence about actions undertaken by firms to accommodate short-term pressure. Such actions may include paying a larger cash dividend or repurchasing more shares, see, e.g., Gaspar et al. (2005). That is, they may lead to a change in the firm's dividend policy. Such changes in turn reduce equity and increase leverage (i.e., they affect the capital structure of the firm). In addition, in order to show better short-term profitability, firms may require a faster payback period for investments, withhold or postpone the use of capital even at the cost of rejecting profitable (NPV >0) long-term investment projects, cut down R\&D expenditure, ${ }^{14}$ and follow a more aggressive employment policy (leading to higher layoffs). Moreover, firms may change their financial reporting practices (see, e.g., Graham et al., 2006). Finally, the results of, e.g., Clay (2000) indicate that shortsighted investment behavior can weaken the corporate governance mechanisms of a firm, leading to, e.g., higher levels of managerial compensation.

We study all the actions discussed above. We presented all respondents with a list of actions and asked to what degree the firm uses them to adjust to the short-term pressure felt. We expect that firms subject to a higher pressure undertake actions to accommodate for the pressure to a higher degree. We also investigate the mitigating role of different large owners by studying whether companies with a large (potentially more long-term) owner of a certain type are less willing to undertake value-destroying actions.

\footnotetext{
${ }^{14}$ For recent survey and evidence, see e.g. Osma and Young (2009) and Chakravarty and Grewal (2011). A willingness to bypass profitable investments for the meeting of earnings targets (earnings smoothing) was also found by Graham et al. (2006) in their survey of CFOs in the U.S. Greenwood and Schor (2009) find that firms subject to entering activist owner experience a significant reduction in capital expenditures.
} 
Hypothesis 3: Firms subject to a higher pressure are more likely to undertake actions to alleviate short-term pressure.

Hypothesis 4: Firms with a large, pressure reducing shareholder are less willing to undertake actions that potentially destroy value (such as postponing investment or reducing $R \& D)$.

\section{DATA}

\subsection{The survey data}

This paper is based on the results of a questionnaire that was directed to all Chairmen of the Boards, CEOs and CFOs of publicly listed firms on a Nordic (Denmark, Finland, Iceland, Norway, and Sweden) stock exchange. Separate questionnaires were sent to the three respondent groups. ${ }^{15}$ However, the questionnaires included some common questions, in particular, in relation to the short-term pressure felt. Our results utilize the common questions and some separate questions directed only to some respondent groups. Appendix 1 of this paper lists the questions used in the survey and to whom they were directed.

The survey was conducted in two stages. In the first stage, the questionnaire was sent to respondents in Nordic firms listed on the exchanges operated by the OMX (now NASDAQ OMX), i.e., in Denmark, Finland, Iceland, and Sweden. This took place in early December 2007. In the second stage, in May 2008, the questionnaire was sent to the respondents in the firms listed at the Oslo Børs in Norway. The questionnaire was sent as a letter directed to a named respondent. The names and addresses of the respondents (i.e., the Chairmen of the Board, the CEOs, and the CFOs) were hand-compiled into a database. Ultimately, the questionnaire was sent to 780 firms with 2271 respondents (although three times 780 is 2340, 69 firms lacked specific CFOs).

\footnotetext{
${ }^{15}$ Much work was put on the optimal design of the questionnaire. Prior to the actual survey, the questionnaire
} was also tested on subsets of executives / board members and like both in Sweden as well as in Finland. 
The respondents were promised total anonymity (i.e., the responses and the identities of the respondents are available only to the researchers and the results are reported only as a group). Responses were obtained from 464 individual respondents representing 352 different firms; four respondents could not be identified (the questionnaire was returned without the identification code). The overall response rate was $20.4 \%$, ranging from $10.3 \%$ for Norway to $29.3 \%$ for Sweden. ${ }^{16}$ The Chairmen were the most active respondents (158 responses), although the response rate was almost the same for all categories of the respondents. Table 1 report the response rates per country and respondent category.

\subsection{Background data}

The responses were matched with background information on firm financials, ownership concentration, and main owner type. The financial data was collected from three sources. Our primary source was the Amadeus database, for lacking items complemented by data from Datastream. Finally, annual reports downloaded from the web provided an additional data source in cases where information was not available in other databases. The financials are from the last reporting year ending before the questionnaire was sent out; mainly yearend 2006 for Denmark, Finland, Iceland, and Sweden, and 2007 for Norway. Year-end exchange rates were used to convert all financials to the same currency, the euro, which is already the currency of Finland. Financial data was collected, not only for responding firms, but also for the whole market. This facilitated relating our sample to the whole population surveyed. Table 2 reports descriptive statistics for the responding firms and the whole population, and these were recorded separately for financial and non-financial firms. ${ }^{17}$ The value of solidity is not reported for the financial firms due to cross-sectional differences in

\footnotetext{
${ }^{16}$ The response rate can be considered to be high for this kind of surveys. For example, Graham et al. (2006) had a response rate of 10.4 per cent in their study.

${ }^{17}$ Many studies restrict their sample strictly to industrial firms, since financial variables such as solidity, and the value of total assets, are on a very different level for financials vs. non-financials. Since our prime focus is the responses to the questionnaire, which do not suffer from differences in measurement, we keep all respondents included. However, we also perform robustness tests using only non-financial firms.
} 
how it is reported (the financial firms group is very heterogeneous and includes, e.g., listed funds or investment companies, as well as insurance companies).

Table 2 shows that the firms that chose to take part in our study are marginally larger than the population of firms to which the questionnaire was sent. This holds for the non-financial firms ( 285 in our sample) for all size related variables, but is true for the financials only in terms of turnover. Our non-financial firms are also marginally less profitable (having a lower return on assets, i.e., ROA), whereas the 57 financials firms in our sample are more profitable. The differences are, however, small and not statistically significant. We therefore conclude that our sample represents the total population quite well.

Ownership data for the firms was collected primarily from Amadeus and secondarily from annual reports obtained from the internet. The Amadeus data represents the ownership situation at the time the survey was taken, whereas the data from the annual reports is from the last reporting year prior to the survey. We collected data on the ownership share (percentage equity) of the largest shareholder, and owner name. ${ }^{18}$ Annual reports as well as internet sources were used to gather information about the largest owner for classification purposes. Private owners (individuals, families) were the largest owner type; 39 percent of 464 respondents worked for such a company, followed by a non-financial firm (16\%), mutual funds (14\%), activist investors (11\%), banks, insurance companies and pension funds (10\%), endowment (4\%), state or municipality (3\%), and co-operatives (1\%). Our private owners include both individuals as well as families. Activist investors, on the other hand, include private equity and venture capitalists, and a few hedge funds, whereas endowments include different types of charities and like. We were unable to identify the biggest owner for sixteen companies.

\footnotetext{
${ }^{18}$ Since pyramiding is not that common in the Nordic countries, the first level of ownership has mostly turned out to also be the ultimate ownership level (i.e. the largest controlling owner typically turns out to be a private person, directly owning the shares, or e.g. a listed firm with a wide-spread ownership, or a large pension fund). We have made efforts to search for the ultimate owner by searching for the owners of small investment companies, which often turn out to be fully owned by one individual or a few members of a family. Such observations are classified as privately owned firms. Our largest owner types are: private (43\% of the large owners), another firm (18\%), an investment fund (12\%), or an activist owner (11\%).
} 


\subsection{Perceived pressure for short-term results}

Our first hypothesis concerns the overall level of pressure to obtain good results in the shortterm, and its relationship to the existence of a large owner of a certain type in the firm. We asked all respondents (Chairmen, CEOs and CFOs) to indicate the degree to which they have experienced external expectations to generate pressure which is in conflict with the longterm goals of the company. Respondents could choose between values on a Likert-type scale, ranging from 1 (very little) to 5 (very much). Panel A of Table 3 reports the results for each respondent category first and then broken down at the country level. Panel B gives the results across all responses.

Table 3 shows that the average pressure felt is intermediate, mainly between 2 and 3 (the overall average is 2.72 ), and this value is comparable with the average of 2.838 reported by Liljeblom and Vaihekoski (2009) for unlisted firms in Finland. There are very few systematic country differences. Iceland is perhaps the only clear exception, but the sample for Iceland is very small. Analysing the responses across the respondents shows that the highest average pressure felt is by the CEO, followed by the CFO, then the CM (Chairman of the Board). This rank holds for all country averages except for Iceland.

In order to test our hypothesis 1, we estimate an ordered probit model using the reported scores for pressure as the dependent variable. As explanatory variables in the base-case, we include first of all sector dummies (industrials and energy, consumer products, IT, and financial firms), and a country dummy for Iceland, the county with on average the highest values for our pressure variable. ${ }^{19}$ Because the pressure can be reported by the CEOs, the CFOs, or the CMs, we also include two dummy variables: a CEO-dummy and CFO-dummy.

\footnotetext{
${ }^{19}$ The sector dummies are insignificant and are not reported in the tables, whereas the country dummy for Iceland is positive and significant across models. Robustness tests reveal that the results are not sensitive to including dummiesfor other countries as well.
} 
Using these coefficients allows us to test for significant differences between these respondent categories versus the chairman, for whom the pressure on average is the lowest, while controlling for other factors.

We also add a variable for the age of the respondent. Fiss and Zajac (2004) included CEO age in their model for shareholder value adaptation, and found that when interacted with an economics or law degree, it had a significant negative effect on the likelihood of a firm espousing a shareholder value orientation. We expect that age proxies for experience and greater independence, and helps in reducing the pressure for short-term actions felt by the respondent. I.e. we expect a negative sign for our variable Resp_age.

To control for external determinants, we include financial variables for size (measured by the natural logarithm of total assets) and profitability (measured as the return on assets, ROA, defined as net profit in percentage of total assets). We expect that the pressure is larger in less profitable firms, whereas for size we do not have a clear ex ante expectation.

Finally, we add our key owner type variables, first for six main owner types: INST for financial institutions and like as large owners, FIRM for a non-financial firm as a large owner, PRIVATE for a large private owner, and CO_OP for a co-operative as a large owner. These variables are dummies taking the value of one if the largest owner owns more than $20 \%$ of the equity in the firm, and belongs to the group in question. Later, we refine our definition for a large institutional owner, using the categories of banks, pension funds, and insurance companies (BANK_PENS_INS), funds and investment companies (FUND), activists (ACTIVIST), and endowments (ENDOWM) as owners. Our model is thus:

Short-term pressure $=\alpha_{0}+\beta_{1}$ (sector-dummy) $+\beta_{2}$ (Iceland-dummy) $+\beta_{3}$ (CEO-dummy) $+\beta_{4}$ (CFO-dummy) $+\beta_{5}$ (Resp_age) $+\beta_{6}$ (Owner type variables) $+\beta_{7}$ (Control variables) $+\varepsilon$, 
where short-term pressure is a response variable ranging from 1 to 5 , a CEO-dummy (CFOdummy) is a binary variable that equals one if the response is given by a CEO (CFO) and zero otherwise, Resp_age is the age of the respondent, and the owner type variables are indicator variables taking the value of 1 if the largest owner owns $20 \%$ of the equity of the firm or more and belongs to a certain owner type category, and zero otherwise. The control variables include In(total_assets) and ROA (defined as net profit divided by the total assets). ${ }^{20}$ Also sector dummies and a country dummy for Iceland are included.

The results from the estimation of a base-case model without owner type variables are reported in Column A of Table 4. The CEO-dummy is significant at the $5 \%$ level, indicating that a CEO experiences a significantly higher pressure for short-term results than the CM, which has no dummy. The pressure felt by the CFO, in turn, is not significantly different from that by the CM. Both financial control variables, In(total_assets) and ROA, are negative and significant. The results for ROA are in line with our prior expectation, as for size, we did not have an ex ante expectation. The results indicate that executives in larger and more profitable firms feel less pressured towards undertaking short-term actions.

Other interesting findings from Table 4, column A, include the dummy for Iceland, as well as Resp_age. Iceland is the only country deviating significantly from the others, with higher pressure for short-term actions felt. This is an interesting observation, since the survey was made in December 2007, i.e. before the main outburst of the financial crisis in Europe in fall 2008, which had a huge effect on the Icelandic economy. Clearly, some country factor, such as the pyramiding ownership structures in Icelandic firms in combination with higher leverage levels, induced such higher short-term pressure already at this stage. The other interesting finding is related to respondent age. A significant negative coefficient for the variable supports our expectation of lower pressure felt by more experienced (older) respondents.

\footnotetext{
${ }^{20}$ Some extreme observations (with ROA below $-80 \%$, 4 observations in the base-case) have been excluded. The results would not have been very different if these would have been included, and the significance of ROA is robust. The results are robust to alternatively winsorizing the profit variable.
} 
In Column B, the main owner type variables have been included. The sign for INST is negative as expected, but the variable is not quite significant which reflect the heterogeneity of the institutional investor class. In column C, INST is divided intodifferent types of institutional owners. According to our hypothesis 1, we expect a negative sign for such institutional owners which are more likely to have a long-term focus, i.e. BANK_PENS_INS, ENDOWM, and ACTIVIST as compared to FUND. The results in Table 4, column C, show that the signs for all institutional owners are negative, indicating less pressure for short-term actions as compared to other large owners, but the coefficients for FUND as well as BANK_PENS_INS are rather small, and they are insignificant, as is ENDOWM. Activist ownership in turn significantly reduces the pressure for undertaking short-term actions.

Next, we perform some robustness tests. In Column D, we run the model used for in Column C, but exclude financial firms. Now not only activist ownership, but also ownership by endowments, significantly reduces short-term pressure. These results are in line with our hypothesis 1 for activist owners and endowments, but not for banks, pension funds and insurance companies as large owners. According to our hypothesis 2, we expect that also other large owners have a pressure reducing impact as compared to firms without any large owners. This hypothesis does not receive support, since the coefficients for FIRM, PRIVATE, STATE_MUN and CO_OP are, with two exceptions (FIRM, and STATE_MUN in column D), positive. None of these are significant.

In summary, our results support the pressure reducing effect of large owners only in case they are a specific kind of long-term owner, such as activist owners or endowments. The results also support the prediction that older, more experienced managers are less likely to feel pressure for short-term actions.

\subsection{Actions taken to alleviate the short-term pressure}

Next, we test the relationship between the degree of short-term pressure and the willingness to adjust the company's performance in response to such pressure. We are above all interested in whether firms are prepared to sacrifice economic value in order to 
meet such pressure for short-term results as indicated by the survey results of Graham et al. (2006). The respondents were presented with a list of actions and asked to what degree their company had undertaken them to accommodate short-term pressure. Respondents could give a value between 1 (very little) and 5 (very much), or 0 (not relevant) for each action. The results are reported in Table 5.

Panel A of Table 5 shows the results for the full sample. The highest score is given for the action financial reporting (3.159) followed by corporate governance (2.986). These are actions that are not necessarily value destroying. However, we also see that actions such as long-term investment (2.887), R\&D expenditure (2.430), and required rate / payback period (2.623) yield reasonably high scores. These actions are more problematic because reducing or postponing investment, using a higher rate of return than motivatedby project risk, or using a shorter payback period, are likely to destroy economic value. Panels B through D of Table 5 show the results for each respondent category (CM, CEO and CFO). The results are rather similar in all three respondent categories, with Financial Reporting and Corporate Governance dominating in all categories.

CFOs were given one alternative that was not available to the others, namely "Special press releases" (not reported in Table 5). The number of respondents here was 139, out of which 16.5 percent considered the alternative as irrelevant for the company. The mean and standard deviation of the responses are 2.784 and 1.133 , respectively.

In order to test our hypothesis 3, we investigate the pairwise correlations between the responses to the overall question of short-term pressure, and these responses on actions. The correlations are all reasonably high, the lowest one being 0.16 (corporate governance) and the highest being 0.39 (hiring / layoff decisions). In ordered probit regressions, using the general scores for the short-term pressure as the explanatory variable and these action responses as the dependent variables each in turn, the slope coefficient is always significant at the $1 \%$ level (the z-values ranged from 2.54 for compensation design to 5.28 for the 
required rate / payback period and 1.92 for the alternative special press releases that was only offered to CFOs). These results are reported in Panel E of Table 5. They give strong support to hypothesis 3 , suggesting that companies that feel a stronger short-term pressure are also more likely to adjust their actions.

We also expect (as specified in hypothesis 4) that the willingness to accommodate for shorttermism is related to the factors that create this pressure, such as the owner type (the time horizon of the owner). To test for this, we regress the same model as in Column C of Table 4, now replacing the dependent variable from general short-term pressure (on a scale form 1 to 5) to the response variable concerning a specific action variable (again on a scale from 1 to 5). I.e. we test whether the degree to which a specific action is undertaken in response to short-term pressure is influenced by the firm's main owner's type. Hypothesis 4 suggests that a long-term institutional owner would reduce the pressure for short-termism, in which case firms also undertake fewer actions to adjust to such a pressure. We estimated the model for each action variable, one by one, using a multivariate ordered probit model with robust standard errors. Although the model includes our full list of owner type variables, Table 6 only reports the coefficients for our three test variables, ACTIVIST, BANK_PENS_INS, and ENDOWM. Table 6 shows that also in this model, activist ownership typically significantly reduces the need to undertake actions to accommodate for short-term pressure, and also ENDOWM does it for certain actions (but is significantly positive for compensation design).

In summary, we find strong support for our hypothesis 3, and also for our hypothesis 4 as far as activist owners are concerned. There is a strong significant relationship between our action variables and our short-term pressure variable, supporting the expectation that firms, in which a higher pressure for short-term actions is felt, also are more likely to undertake such actions. The likelihood for such actions is in turn significantly reduced by the presence of a large owner of one specific type, activists. 


\subsection{Additional considerations and robustness tests}

We also perform some additional robustness test of hypothesis 1 . First, we estimate the sensitivity of our results to the scale ( 1 to 5 for pressure) used in the survey by re-estimating our main models in Table 4 using only the responses that are different from 3 (the intermediate pressure category), and excluding chairman responses. Although we lose a substantial number of observations, the main model is robust to this change and the coefficient for activists is still significantly negative. We also perform other robustness tests. The results in Table 4, column C, are e.g. robust to the inclusion of a full set (four, i.e. all but one) country dummies. The results concerning activists are also robust to using a probit model where only a binary variable, indicating a high (4 or 5) or a low level of pressure felt.

Finally, we perform additional tests to study whether the short-term pressure in the questionnaire is indeed negative (harmful) for the firm. In the survey, we tried to control for this by carefully formulating the main question; we tried not to ask about the short-term pressure as such, but the extent to which the short-term external expectations are in conflict with the long-term goals of the firm. In order to test further for what the responses we obtained are a proxy for, we regress firm profitability on our pressure variable, including also typical firm level controls (size and solidity). Because studies of the relationship between corporate control and firm performance have indicated that the existence of a large owner can be beneficial at least to a certain point (due to reduced agency costs) until an entrenchment effect may kick in (i.e., another type of conflict may be created, this time between the large controlling owner and other owners; typically associated with the large owner having voting rights in excess of control rights) ${ }^{21}$ we also include OWN_20, a variable measuring the percentage of equity owned by the largest owner. The results are reported in Table 7 for different model specifications.

\footnotetext{
${ }^{21}$ See e.g. Morck, Shleifer, and Vishny (1988) and McConnell and Servaes (1990) for an inverse U-shape effect of managerial ownership, and e.g. Cronqvist and Nilsson (2003) for the benefits vs. disadvantages of increases in cash flow vs. voting rights of the controlling owner.
} 
The results in Table 7 show that our pressure variable is - together with firm size - one of the strongest explanatory variables for firm performance as measured through either ROA or ROE. Additional specification tests (not reported here) show that pressure is equally significant when the variable OWN_20 in Table 7 is replaced by the same eight dummies for different types of large investors as used in the models in columns $C$ and D of Table 4. Our pressure variable yields consistently a negative sign, supporting the idea that what we have captured through our survey is indeed the kind of pressure for short-term results that is negatively related to profitability.

Naturally, the results in Tables 4 and 7 are subject to the issue of endogeneity due to the uncertainty of the direction of a causal relationship. Observing lower short-term pressure in companies with activist owners can be caused by the either by a true causal relationship from ownership to the company, but the relationship can also run the other way around. I.e., activists may choose to invest in companies with lower agency costs and as a result, the pressure to perform in the short-run is low.

\section{CONCLUSIONS}

This paper builds on earlier results from several studies indicating that short-term pressure may influence firms to undertake actions that sacrifice economic value in order to meet short-term benchmarks. We focus especially on the question whether a large, long-term institutional owner can mitigate such pressure for short-termism. Although the effects of institutional owners have been subject to a number of studies, the results are typically mixed and indicate that the category of institutional owners include both owners with a short horizon (such as mutual funds and investment companies) as well as owners with a longer horizon. E.g. public pension funds have been suggested as examples of owners with a longer horizon, see e.g. Kochhar and David (1996), Hoskisson et al. (2002), and Zouari and Rebai (2009), whereas mutual funds have been blamed for their frequent trading and short-term performance incentives (e.g. Hoskisson et al., 2002; Suto and Toshino, 2005). 
We contribute to the earlier literature by studying a broad category of different owner types, including several subgroups of institutional owners. We study the effect of owner type in a rich dataset including, from five Nordic countries, CEO, CFO, and chairman responses both concerning the degree of short-term pressure felt, as well as their willingness to undertake a set of actions in order to accommodate for such a pressure. The Nordic markets offer an excellent opportunity to study the impacts of different types of large owners, as there is substantial variation in ownership levels and types as compared to, e.g., the U.S., where firms are typically widely held and where institutional owners dominate. Using recent survey data for 464 executives from firms listed in Denmark, Finland, Iceland, Norway and Sweden accompanied with information on firm financials and the percentage of equity of the largest owners in the firm, and owner types, we studied the levels, determinants, and consequences of perceived short-term pressure.

Our main results relate to the impact of a specific active owner type, activists. We add to the literature on the performance effects by active ownership (see e.g. David et al., 2001; Mietzner et al., 2008) by reporting on the short-term pressure reducing effects of activists. The results are interesting, since they are in contradiction with some earlier results (e.g. Greenwood and Schor, 2009) where entering activists instead seem to cause actions which may be interpreted as a reduction in the long-term focus of the firm (such as a significant reduction in capital expenditures). We in turn find that in firms with a large activist owner, significantly less pressure for short-term actions is felt, and significantly less need to undertake actions (such as changes in R\&D investments) to accommodate for such pressure are undertaken. In this way, our results relate to the recent findings of, e.g., Klein (2002), Becker et al. (2011), as well as Brockman and Yan (2009), who indicate that a large shareholder or a large and active blockholder can have an effect in, e.g., reducing earnings manipulation, increasing the profitability of the firm, reducing executive compensation, and shaping the firm's information environment.

We also add to prior studies by looking at some behavioral differences. First, we look at different director categories separately (the CEO, the CFO, and the Chairman of the board). 
This distinction has not been made before in studies of short-term effects. Among the executives, the CEO feels the strongest pressure, followed by the CFO. In line with e.g. Fiss and Zajac (2004) in a study of the adaptation of shareholder value, we include the age of the respondent. In line with our expectation concerning the effect of experience, we find that older respondents feel significantly less pressure for short-term actions.

Our results contribute to the literature on short-term pressure and to the corporate governance literature concerning the effects of corporate control. The results indicate that the need to put corporate governance mechanisms in place to reduce managerial myopia are of special interest in firms that are subject to a higher pressure for short-term results due to the lack of an active owner. Our results indicate that activist ownership is especially beneficial in this sense. The need for such incentives is also stronger for young managers, as older executives seem to be less sensitive to such short-term pressure. Such mechanisms include, e.g., compensation systems with a longer-term focus. 


\section{REFERENCES}

Baysinger B, Kosnik R, Turk, T. 1991. Effects of board and ownership structure on corporate R\&D strategy. Academy of Management Journal 34: 205-214.

Becht, M., Franks, J., Mayer, C., Rossi, S. 2009. Returns to Shareholder Activism: Evidence from a Clinical Study of the Hermes UK Focus Fund. The Review of Financial Studies 22, 3093-3129.

Becker B, Cronqvist H, Fahlenbrach R. 2011. Estimating the effect of large shareholders using a geographic instrument. Journal of Financial and Quantitative Analysis 46: 907-942.

Bethel, JE., Liebeskind, JP, Opler, T. 1998. Block share purchases and corporate performance. Journal of Finance 53: 605-634.

Brav, A., Jiang, W., Partnoy, F., Thomas, R. 2008. Hedge fund activism, corporate governance, and firm performance. Journal of Finance 63, 1729-1775.

Brockman P, Khurana I, Martin X. 2008. Voluntary disclosures around actual share repurchases. Journal of Financial Economics 89: 175-191

Brockman P, Yan X. 2009. Block ownership and firm-specific information. Journal of Banking and Finance 33: 308-316.

Burns N, Kedia S, Lipson M. 2010. Institutional ownership and monitoring: Evidence from financial misreporting. Journal of Corporate Finance 16: 443-455.

Bushee B. 1998. The influence of institutional investors on myopic R\&D investment behavior. The Accounting Review 73: 305-333.

Bushee BJ. 2001. Do institutional investors prefer near-term earnings over long-run value? Contemporary Accounting Research 18: 207-246.

Chakravarty A, Grewal R. 2011. The stock market in the driver's seat! Implications for R\&D and marketing. Management Science 57(9): 1595-1609.

Chen X, Harford J, Li K. 2007. Monitoring: which institutions matter? Journal of Financial Economics 86: 279-305.

Clay D. 2000. The effects of institutional investment on CEO compensation. Working paper, University of Southern California.

Clifford, C. 2008. Value creation or destruction? Hedge funds as shareholder activists. Journal of Corporate Finance 14, 323-336.

Cronqvist H, Nilsson M. 2003. Agency costs of controlling minority shareholders. Journal of Financial and Quantitative Analysis 38: 695-719.

Cronqvist H, Fahlenbrach R. 2009. Large shareholders and corporate policies. The Review of Financial Studies 22: 3941-3976.

David P., Kochhar, R. 1996. Barriers to corporate governance by institutional investors: Implications for theory and practice. European Management Journal 14: 457-466.

David P, Hitt MA, Gimeno J. 2001. The influence of activism by institutional investors on R\&D. Academy of Management Journal 44(1): 144-157. 
Edmans A. 2009. Blockholder trading, market efficiency, and managerial myopia. Journal of Finance 64(6): 2481-2513.

Edwards FR, Hubbard RG. 2000. The growth of institutional stock ownership: A promise unfulfilled. Journal of Applied Corporate Finance 13(3): 92-104.

Fiss PC, Zajac EJ. 2004. The diffusion of ideas over contested terrain: the (non)adoption of a shareholder value orientation among German firms. Administrative Science Quarterly 49: 501-534.

Gaspar J-M, Massa M, Matos P, Patgiri R, Rehman Z. 2005. Can buybacks be a product of shorter shareholder horizons? CEPR discussion paper 4813.

Gillian SL, Starks LT. 2003. Corporate governance, corporate ownership, and the role fo institutional investors: A global perspective. Journal of Applied Finance 13: 4-22.

Graham JR, Harvey CR, Rajgopal S. 2006. Value destruction and financial reporting decisions. Financial Analyst Journal 62: 27-39.

Graves SB. 1988. Institutional ownership and corporate R\&D in the computer industry. Academy of Management Journal 31: 417-428.

Greenwood R, Schor M. 2009. Investor activism and takeovers. Journal of Financial Economics 92: 362-375.

Hansen GS, Hill CWL. 1991. Are institutional investors myopic? A time-series study of four technology-driven industries, Strategic Management Journal 12: 1-16.

Holderness C. 2003. A survey of blockholders and corporate control. Economic Policy Review 9: 1-14.

Hoskisson RE, Hitt MA, Johnson RA, Grossman W. 2002. Conflicting voices: The effects of institutional ownership heterogeneity and internal governance on corporate innovation strategies. Academy of Management Journal 45(4): 697-716.

Klein A. 2002. Audit committee, board of director characteristics, and earnings management. Journal of Accounting and Economics 33: 375-400.

Klein, A., Zur, E. 2009. Entrepreneurial Shareholder Activism: Hedge Funds and Other Private Investors. Journal of Finance 64, 187-229.

Kochhar R, David P. 1996. Institutional investors and firm innovation: A test of competing hypotheses. Strategic Management Journal 17: 73-84.

Koh P-S. 2003. On the association between institutional ownership and aggressive corporate earnings management in Australia. The British Accounting Review 35(2): 105-128.

Koh P-S, Hsu GC. 2005. Does the presence of institutional investors influence accruals management? Evidence from Australia. Corporate Governance: An International Review 13: 809-823.

Lee P, O'Neill H. 2003. Ownership structures and R\&D investment of U.S. and Japanese firms: agency and stewardship perspectives. Academy of Management Journal 46: 212-225.

Lee, PM. 2005. A comparison of ownership structures and innovations of US and Japanese firms. Managerial and Decision Economics 26: 39-50. 
Liljeblom E, Vaihekoski M. 2009. Corporate ownership and managerial short-termism: results from a Finnish study of management perceptions. International Journal of Production Economics 117(2): 427-438.

Marquardt CA, Tan CEL, Young SM. 2009. Accelerated share repurchases, bonus compensation, and CEO horizons. Working paper, City University of New York.

McConnell JJ, Servaes H. 1990. Additional evidence on equity ownership and corporate value. Journal of Financial Economics 27: 595-612.

Mietzner M, Schweizer D, Tyrell M. 2008. ) Intra-Industry Effects of Shareholder Activism in Germany - Is There a Difference between Hedge Fund and Private Equity Investments? Schmalenbach Business Review 63:151-185

Morck R, Scheifer A, Vishney RW. 1988. Management ownership and market valuation. Journal of Financial Economics 20: 293-315.

Osma BG, Young SE 2009. R\&D expenditure and earnings targets. European Accounting Review 18: 732.

Ozer M, Alakent E, Ahsan M. 2010. Institutional ownership and corporate political stategies: Does heterogeneity of institutional owners matter? Strategic Management Review 4(1): 18-29.

Shleifer A, Vishny RW. 1997. A survey of corporate governance. Journal of Finance 52: 737-783.

Suto M, Toshino M. 2005. Behavioural biases of Japanese institutional investors: fund management and corporate governance. Corporate Governance: An International Review 13: 466-477.

Tribo JA, Berrone P, Surroca J. 2007. Do the type and number of blockholders influence R\&D investments? New evidence from Spain. Corporate Governance: An International Review 15: 828842.

Zahra SA. 1996. Governance, ownership, and corporate entrepreneurship. Academy of Management Journal 39: 1713-1735.

Zouari A, Rebai I. 2009. Institutional ownership differences and earnings management: A neural network application. International Research Journal of Finance and Economics 34: 42-55. 
Appendix 1. The questions from the survey included in this study, and their respondent categories. Questions 1-3 were directed to all respondents (last item on question 3 was only included for CFOs questionnaire) and questions 4 only to the CFOs.

\section{Short-term external expectations:}

To what extent do You feel that short-term external expectations generate conflict with company's long-term goals?

\begin{tabular}{|l|l|l|l|l|}
\multicolumn{2}{c}{ very little } & -- & \multicolumn{2}{c}{ very much } \\
$\mathbf{1}$ & $\mathbf{2}$ & $\mathbf{3}$ & $\mathbf{4}$ & $\mathbf{5}$ \\
\hline & & & & \\
\hline
\end{tabular}

2. What actions has Your Company taken, if any, to accommodate short-term expectations and how often?

not

very little --- very much

relevant

Compensation design

Dividend policy

Capital structure

Long-term investments

Hiring / layoff decisions

$R \& D$ expenditure

Financial reporting

Corporate Governance

Required rate / Payback

period

\begin{tabular}{|l|l|l|l|l|}
$\mathbf{1}$ & $\mathbf{2}$ & 3 & $\mathbf{4}$ & $\mathbf{5}$ \\
\hline & & & & \\
\hline & & & & \\
\hline & & & & \\
\hline & & & & \\
\hline & & & & \\
\hline & & & & \\
\hline & & & & \\
\hline & & & & \\
\hline
\end{tabular}

0

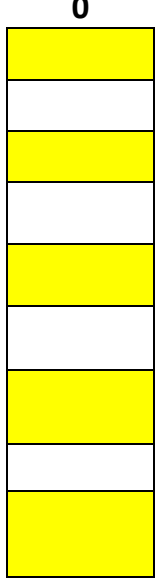


TABLE 1. Descriptive statistics

Descriptive statistics are reported for the responses received from a survey directed to the Chairmen (CM), Chief Executive Officers (CEOs), and Chief Financial Officers (CFOs) of all companies listed at the Nordic Stock Exchanges at the end of 2007 (all but Norway) and in May 2008 (Norway). A total of 780 companies were included and 2271 surveys sent.

\begin{tabular}{lcccc}
\hline \hline & CM & CEO & CFO & Sum \\
\hline Panel A: Number of responses & & & & \\
\hline Denmark & 36 & 32 & 32 & 100 \\
Finland & 18 & 30 & 24 & 72 \\
Iceland & 4 & 3 & 6 & 13 \\
Norway & 20 & 14 & 24 & 58 \\
Sweden & 80 & 70 & 71 & 221 \\
TOTAL & 158 & 149 & 157 & 464 \\
\hline Panel B: Response rates (\%) & $19.1 \%$ & $17.0 \%$ & $25.0 \%$ & $19.8 \%$ \\
\hline Denmark & $13.8 \%$ & $23.1 \%$ & $18.8 \%$ & $18.6 \%$ \\
Finland & $18.2 \%$ & $13.6 \%$ & $33.3 \%$ & $21.0 \%$ \\
Iceland & $10.6 \%$ & $7.4 \%$ & $12.9 \%$ & $10.3 \%$ \\
Norway & $31.7 \%$ & $27.8 \%$ & $28.3 \%$ & $29.3 \%$ \\
Sweden & & $19.1 \%$ & $22.1 \%$ & $20.4 \%$ \\
\hline \hline
\end{tabular}




\section{TABLE 2. Descriptive statistics for responding firms and target population}

Descriptive statistics are reported for the listed firms in Denmark, Finland, Iceland, Norway and Sweden (the "Population", a total of 780 firms), which were targeted in the survey (whose Chairman of the Board, CEOs and CFOs obtained the questionnaire). We also report statistics for responding firms (the "Sample", a total of 352 firms), i.e. firms from which at least one respondent returned a filled-in questionnaire. The firms are divided into Financials (banks, investment and insurance companies) and Non-financials, based on the sector codes used by the OMX exchanges and Oslo Børs (both use same ten categories). We report averages, medians, standard deviations, and the number of firms for which the financial information item has been obtained ("Obs"), for the following variables: Turnover (in 1000 euros), No. of employees, Total assets (in 1000 euros), Return on total assets (ROA, defined as Net Profit to Total Assets) and Solidity (defined as Equity to Total Assets). Financial data is for the last available reporting year prior to the date for sending out the questionnaire (typically 2007 for Norway, and 2006 for the others), and has been collected from Amadeus, Datastream, and annual reports for the companies.

Non-financials

Sample
Population
Financials

Sample
Population

\begin{tabular}{|c|c|c|c|c|c|}
\hline Firms & & 285 & 615 & 67 & 165 \\
\hline Turnover, & Mean & 1280296 & 1058814 & 736835 & 543775 \\
\hline \multirow[t]{3}{*}{1000 EUR } & Median & 106970 & 101826 & 94865 & 53981 \\
\hline & St.dev. & 4675704 & 3939259 & 1946139 & 2039941 \\
\hline & Obs & 280 & 604 & 57 & 142 \\
\hline No of & Mean & 4539 & 4405 & 1494 & 1520 \\
\hline \multirow[t]{3}{*}{ exployees } & Median & 482 & 396 & 190 & 135 \\
\hline & St.dev. & 16653 & 22460 & 4403 & 4679 \\
\hline & Obs & 272 & 569 & 59 & 139 \\
\hline Total assets, & Mean & 1285241 & 1049915 & 12054523 & 12379270 \\
\hline \multirow[t]{3}{*}{1000 EUR } & Median & 107249 & 102364 & 690387 & 570934 \\
\hline & St.dev. & 4562082 & 3696905 & 48051720 & 53042764 \\
\hline & Obs & 285 & 615 & 67 & 165 \\
\hline ROA, & Mean & 4.13 & 4.22 & 6.86 & 5.95 \\
\hline \multirow[t]{3}{*}{ per cent } & Median & 7.34 & 6.40 & 3.88 & 2.40 \\
\hline & St.dev. & 17.61 & 16.28 & 9.18 & 9.64 \\
\hline & Obs & 283 & 613 & 67 & 162 \\
\hline
\end{tabular}


Solidity,

per cent

Median

St.dev.

Obs
47.72

45.43

19.35

282
49.07

45.58

20.11

610 
TABLE 3. Pressure on compromising long-term goals in favor of short-term goals

Respondents were asked to indicate the degree to which they have experienced that external expectations generate a conflict with the company's long-term goals. Answers were given on a 1 (very little) to 5 (very much) scale. Panels from A to C report the results for the Chairman, CEOs, and CFOs, respectively, and Panel $D$ for all respondents combined. Results are reported for each country separately and across all countries. $N$ and $N_{\text {empty }}$ are total number of respondents with non-empty (empty) reply, respectively.

\begin{tabular}{|c|c|c|c|c|c|}
\hline & $\mathbf{N}$ & Mean & Median & Std. dev. & $\mathbf{N}_{\text {Empty }}$ \\
\hline \multicolumn{6}{|c|}{ Panel A: Chairman } \\
\hline Denmark & 32 & 2.38 & 2.00 & 1.07 & 4 \\
\hline Finland & 17 & 2.18 & 2.00 & 1.07 & 1 \\
\hline Iceland & 4 & 3.25 & 3.00 & 0.50 & 0 \\
\hline Norway & 19 & 2.42 & 2.00 & 1.30 & 1 \\
\hline Sweden & 77 & 2.65 & 3.00 & 1.10 & 3 \\
\hline All & 149 & 2.52 & 2.00 & 1.12 & 9 \\
\hline \multicolumn{6}{|c|}{ Panel B: CEO } \\
\hline Denmark & 31 & 2.90 & 3.00 & 1.01 & 1 \\
\hline Finland & 27 & 3.33 & 4.00 & 1.11 & 3 \\
\hline Iceland & 3 & 2.33 & 2.00 & 1.53 & 0 \\
\hline Norway & 14 & 3.43 & 4.00 & 0.94 & 0 \\
\hline Sweden & 66 & 2.67 & 3.00 & 1.18 & 4 \\
\hline All & 141 & 2.91 & 3.00 & 1.14 & 8 \\
\hline \multicolumn{6}{|c|}{ Panel C: CFO } \\
\hline Denmark & 29 & 2.59 & 3.00 & 1.18 & 3 \\
\hline Finland & 24 & 2.67 & 3.00 & 1.09 & 0 \\
\hline Iceland & 6 & 3.17 & 3.00 & 0.75 & 0 \\
\hline Norway & 23 & 2.89 & 3.00 & 1.22 & 1 \\
\hline Sweden & 68 & 2.72 & 3.00 & 0.99 & 3 \\
\hline All & 150 & 2.73 & 3.00 & 1.07 & 7 \\
\hline
\end{tabular}




\begin{tabular}{lccccc}
\hline Panel D: All combined & & & & & \\
\hline Denmark & 92 & 2.62 & 3.00 & 1.10 & 8 \\
Finland & 68 & 2.81 & 3.00 & 1.18 & 4 \\
Iceland & 13 & 3.00 & 3.00 & 0.91 & 0 \\
Norway & 56 & 2.87 & 3.00 & 1.23 & 2 \\
Sweden & 211 & 2.67 & 3.00 & 1.10 & 10 \\
All & 440 & 2.72 & 3.00 & 1.12 & 24 \\
\hline \hline
\end{tabular}




\section{TABLE 4. Short-term pressure and firm ownership}

The table reports the results from multivariate ordered probit-models, where short-term pressure (a response score from 1 to 5 ) is the dependent variable. The explanatory variables are: Ice_dummy, a country dummy for Iceland; CEO-dummy (CFO-dummy), taking the value of 1 if the response is given by a CEO (CFO) and zero otherwise; the natural logarithm of total assets; net profit over total assets (ROA); the age of the respondent; INST, a dummy for a large institutional owner, or broken down into banks, pension funds, and insurance companies (BANK_PENS_INS), funds and investment companies (FUND), private equity (ACTIVIST), and endowments (ENDOWM); dummies for other large owners: a non-financial firm (FIRM), a private owner (PRIVATE), a state or a municipality (STATE_MUN), or a co-operative (CO_OP). Sector dummies are included. Model $A$ is the base-case. In model B, five owner types are included. In model $C$, institutional owners are split into four subgroups. Model $D$ finally excludes observations from the financial sector. Models are estimated with robust and clustered standard errors for observations from the same firm. Z-scores are provided below the parameter estimates. ${ }^{*}\left({ }^{*}\right)$ denotes significance at the $5 \%(1 \%)$ levels, one-sided tests.

\begin{tabular}{lllll}
\hline \hline Model & Model A & Model B & Model C & Model D \\
\hline Ice_dummy & $0.6319^{* *}$ & $0.6395^{* *}$ & $0.5863^{* *}$ & $0.4138^{*}$ \\
& 4.49 & 4.10 & 3.54 & 2.34 \\
CEO-dummy & $0.2976^{*}$ & $0.2794^{*}$ & $0.2920^{*}$ & 0.2389 \\
& 2.00 & 1.84 & 1.93 & 1.43 \\
CFO-dummy & 0.0279 & -0.0004 & 0.0071 & -0.0419 \\
& 0.19 & -0.00 & 0.05 & -0.26 \\
In(total_assets) & $-0.0491^{*}$ & -0.0417 & -0.0397 & -0.0314 \\
& -1.71 & -1.39 & -1.31 & -0.89 \\
Resp_age & $-0.0095^{*}$ & $-0.0105^{* *}$ & $-0.0108^{* *}$ & $-0.0118^{* *}$ \\
& -2.25 & -2.60 & -2.67 & -2.79 \\
& $-0.0121^{*}$ & $-0.0128^{*}$ & $-0.0126^{*}$ & $-0.0158^{*}$ \\
& -1.72 & -1.80 & -1.78 & -2.03 \\
& & & &
\end{tabular}

INST

$-0.2247$

$-1.56$

\begin{tabular}{|lcc|}
\hline BANK_PENS_INS & -0.0614 & -0.2039 \\
& -0.24 & -0.52 \\
\hline FUND & -0.0543 & -0.1622 \\
& -0.22 & -0.50 \\
\hline ACTIVIST & $-0.3735^{*}$ & $-0.4009 *$ \\
\hline
\end{tabular}




\begin{tabular}{|c|c|c|c|c|}
\hline & & & -1.82 & -1.92 \\
\hline \multicolumn{3}{|l|}{ ENDOWM } & -0.4064 & $-0.6369 *$ \\
\hline \multirow[t]{2}{*}{ FIRM } & & 0.0685 & 0.0564 & -0.0017 \\
\hline & & 0.37 & 0.30 & -0.01 \\
\hline \multirow[t]{2}{*}{ PRIVATE } & & 0.1615 & 0.1576 & 0.1822 \\
\hline & & 1.15 & 1.12 & 1.19 \\
\hline \multirow[t]{2}{*}{ STATE_MUN } & & 0.1087 & 0.0978 & -0.0266 \\
\hline & & 0.29 & 0.26 & -0.06 \\
\hline \multirow[t]{2}{*}{ CO_OP } & & 0.3606 & 0.1178 & 0.0804 \\
\hline & & 0.76 & 0.25 & 0.17 \\
\hline Obs (N) & 403 & 402 & 402 & 331 \\
\hline Wald $\mathrm{Chi}^{2}$ & 44.10 & 52.08 & 55.88 & 57.12 \\
\hline Pseudo $\mathrm{R}^{2}$ & 0.0256 & 0.0304 & 0.0317 & 0.0358 \\
\hline
\end{tabular}


The respondents were asked which actions, if any, their company had taken to accommodate short-term pressure. The respondents were given a list of actions and they could respond 1 (very little) through to 5 (very much) as well as 0 (not relevant). Panel A reports the results for the full sample and Panels $B$ to $D$ for the Chairmen, CEOs, and CFOs. $\mathrm{N}$ indicates the number of respondents, with the response rate in parenthesis. The not relevant (\%) column reports the number of responses indicating that the question is not relevant for the company. The reported mean, median and standard deviation are calculated from valid responses between one and five. Finally, Panel E reports the results from ordered probit models (using robust standard errors) using the action response scores as dependent variables and the response scores to the general question on short-term pressure as the single explanatory variable in each model. ${ }^{*}$ denotes significance at least at the $10 \%$ level.

\begin{tabular}{|c|c|c|c|c|c|}
\hline & $\mathbf{N}$ & Mean & Median & Std. dev. & $\begin{array}{c}\text { Not relevant } \\
\text { (\%) }\end{array}$ \\
\hline \multicolumn{6}{|l|}{ Panel A: Full sample } \\
\hline Compensation design & 428 & 2.739 & 3 & 1.122 & $25.7 \%$ \\
\hline Dividend policy & 430 & 2.736 & 3 & 1.211 & $21.9 \%$ \\
\hline Capital structure & 430 & 2.797 & 3 & 1.149 & $17.4 \%$ \\
\hline Long-term investments & 430 & 2.887 & 3 & 1.181 & $17.4 \%$ \\
\hline Hiring / layoff decisions & 429 & 2.500 & 2 & 1.181 & $24.9 \%$ \\
\hline$R \& D$ expenditure & 427 & 2.430 & 2 & 1.182 & $28.6 \%$ \\
\hline Financial reporting & 431 & 3.159 & 3 & 1.121 & $14.2 \%$ \\
\hline Corporate Governance & 430 & 2.986 & 3 & 1.118 & $16.3 \%$ \\
\hline Required rate / Payback period & 424 & 2.623 & 3 & 1.132 & $30.0 \%$ \\
\hline \multicolumn{6}{|l|}{ Panel B: Chairmen } \\
\hline Compensation design & 148 & 2.689 & 3 & 1.081 & $28.4 \%$ \\
\hline Dividend policy & 147 & 2.700 & 3 & 1.282 & $25.2 \%$ \\
\hline Capital structure & 147 & 2.838 & 3 & 1.217 & $20.4 \%$ \\
\hline Long-term investments & 147 & 2.809 & 3 & 1.283 & $21.8 \%$ \\
\hline Hiring / layoff decisions & 147 & 2.324 & 2 & 1.204 & $30.6 \%$ \\
\hline R\&D expenditure & 147 & 2.450 & 2 & 1.201 & $32.0 \%$ \\
\hline
\end{tabular}




$\begin{array}{lccccc}\text { Financial reporting } & 149 & 3.098 & 3 & 1.174 & 18.1 \% \\ \text { Corporate Governance } & 147 & 3.000 & 3 & 1.085 & 18.4 \% \\ \text { Required rate / Payback period } & 146 & 2.606 & 3 & 1.114 & 32.2 \%\end{array}$

TABLE 5. Continued

\begin{tabular}{|c|c|c|c|c|c|}
\hline & $\mathbf{N}$ & Mean & Median & & Std. dev. \\
\hline \multicolumn{6}{|l|}{ Panel C: CEOs } \\
\hline Compensation design & 144 & 2.893 & 3 & 1.111 & \\
\hline Dividend policy & 142 & 2.768 & 3 & 1.185 & \\
\hline Capital structure & 143 & 2.737 & 3 & 1.158 & \\
\hline Long-term investments & 143 & 2.959 & 3 & 1.126 & \\
\hline Hiring / layoff decisions & 142 & 2.741 & 3 & 1.097 & \\
\hline R\&D expenditure & 142 & 2.533 & 2 & 1.153 & \\
\hline Financial reporting & 142 & 3.081 & 3 & 1.135 & \\
\hline Corporate Governance & 142 & 3.033 & 3 & 1.173 & \\
\hline \multicolumn{6}{|l|}{ Required rate / Payback } \\
\hline period & 143 & 2.792 & 3 & 1.123 & \\
\hline \multicolumn{6}{|l|}{ Panel D: CFOs } \\
\hline Compensation design & 136 & 2.642 & 3 & & 1.167 \\
\hline Dividend policy & 141 & 2.739 & 3 & & 1.175 \\
\hline Capital structure & 140 & 2.817 & 3 & & 1.077 \\
\hline Long-term investments & 140 & 2.889 & 3 & & 1.135 \\
\hline Hiring / layoff decisions & 140 & 2.429 & 2 & & 1.213 \\
\hline R\&D expenditure & 138 & 2.304 & 2 & & 1.192 \\
\hline Financial reporting & 140 & 3.296 & 4 & & 1.047 \\
\hline
\end{tabular}


Required rate / Payback

period

3

1.150

Panel E: Testing the relationship between pressure and specific actions

\begin{tabular}{|c|c|c|c|c|}
\hline Action & Coeff. for pressure & z-score & Obs & Pseudo $\mathbf{R}^{2}$ \\
\hline Compensation design & $0.1361 *$ & 2.54 & 310 & 0.0071 \\
\hline Dividend policy & $0.1349 *$ & 2.54 & 327 & 0.0065 \\
\hline Capital structure & $0.1831 *$ & 3.47 & 347 & 0.0118 \\
\hline Long-term investments & $0.2116^{*}$ & 4.05 & 347 & 0.0157 \\
\hline Hiring / layoff decisions & $0.2280^{*}$ & 4.28 & 316 & 0.0199 \\
\hline R\&D expenditure & $0.2095^{*}$ & 3.76 & 298 & 0.0162 \\
\hline Financial reporting & $0.2214^{*}$ & 4.20 & 363 & 0.0185 \\
\hline Corporate Governance & $0.1799 *$ & 3.56 & 353 & 0.0126 \\
\hline Required rate / Payback period & $0.2975^{*}$ & 5.28 & 291 & 0.0332 \\
\hline Special press releases (CFO only) & $0.1749 *$ & 1.92 & 115 & 0.0104 \\
\hline
\end{tabular}


TABLE 6. Firm owner type and propensity to take actions to reduce short-term pressure

The table reports results from regressing each response on our action questions (responses given on a scale from one to five) one by one on the same explanatory variables as in model $\mathrm{C}$ in Table 4 again using a multivariate ordered probit-model. We report only the coefficients obtained for three institutional owner type variables, i.e. the ownership types which we according to our hypothesis 1 expected to most reduce pressure for short-term actions: ACTIVIST, BANK_PENS_INS, and ENDOWM. The models are estimated using robust standard errors. Z-scores are provided below the parameter estimates. * denotes significance at least at the $5 \%$ level, and ${ }^{* *}$ at the $1 \%$ level, one-sided tests.

\begin{tabular}{|c|c|c|c|c|}
\hline \multicolumn{4}{|c|}{ Explanatory variable } & \multirow{2}{*}{$\begin{array}{c}\text { Statistics } \\
\text { Obs (N) } \\
\text { Pseudo } \mathbf{R}^{2}\end{array}$} \\
\hline Dependent action variable & ACTIVIST & $\underset{\text { BANK_PENS }}{\text { _INS }}$ & ENDOWM & \\
\hline Compensation design & $\begin{array}{c}-0.6789 * * \\
-3.01\end{array}$ & $\begin{array}{l}0.2000 \\
0.41\end{array}$ & $\begin{array}{c}1.0352 * * \\
2.42\end{array}$ & $\begin{array}{r}294 \\
0.0393\end{array}$ \\
\hline Dividend policy & $\begin{array}{c}-0.9117 * * \\
-3.63\end{array}$ & $\begin{array}{l}0.0149 \\
0.03\end{array}$ & $\begin{array}{c}0.1727 \\
0.69\end{array}$ & $\begin{array}{r}309 \\
0.0315\end{array}$ \\
\hline Capital structure & $\begin{array}{c}-0.5696^{* *} \\
-2.35\end{array}$ & $\begin{array}{l}0.0136 \\
0.02\end{array}$ & $\begin{array}{c}0.3313 \\
1.00\end{array}$ & $\begin{array}{r}324 \\
0.0277\end{array}$ \\
\hline Long-term investments & $\begin{array}{c}-0.5293 * \\
-2.05\end{array}$ & $\begin{array}{l}-0.3435 \\
-0.57\end{array}$ & $\begin{array}{c}0.2395 \\
0.81\end{array}$ & $\begin{array}{c}321 \\
0.0145\end{array}$ \\
\hline Hiring / layoff decisions & $\begin{array}{l}-0.4167 \\
-1.40 \\
\end{array}$ & $\begin{array}{l}-0.1385 \\
-0.26 \\
\end{array}$ & $\begin{array}{c}-0.7381^{*} \\
-1.69 \\
\end{array}$ & $\begin{array}{c}295 \\
0.04115 \\
\end{array}$ \\
\hline$R \& D$ expenditure & $\begin{array}{c}-0.9444 * * \\
-2.47\end{array}$ & $\begin{array}{l}-0.3826 \\
-0.69\end{array}$ & $\begin{array}{c}-0.7377 * * \\
-2.47\end{array}$ & $\begin{array}{c}283 \\
0.0656\end{array}$ \\
\hline Financial reporting & $\begin{array}{c}-0.4860 * \\
-2.11\end{array}$ & $\begin{array}{l}0.1261 \\
0.29\end{array}$ & $\begin{array}{c}0.0864 \\
0.34\end{array}$ & $\begin{array}{r}336 \\
0.0194\end{array}$ \\
\hline Corporate Governance & $\begin{array}{c}-0.7424 * * \\
-2.56\end{array}$ & $\begin{array}{l}0.0073 \\
0.01\end{array}$ & $\begin{array}{l}-0.1386 \\
-0.39\end{array}$ & $\begin{array}{c}327 \\
0.0298\end{array}$ \\
\hline $\begin{array}{l}\text { Required rate / Payback } \\
\text { period }\end{array}$ & $\begin{array}{c}-0.6872 * \\
-2.12\end{array}$ & $\begin{array}{l}-0.3035 \\
-0.51\end{array}$ & $\begin{array}{c}0.4724 \\
1.05\end{array}$ & $\begin{array}{c}271 \\
0.0213\end{array}$ \\
\hline $\begin{array}{l}\text { Special press releases }(\mathrm{CFO} \\
\text { only) }\end{array}$ & $\begin{array}{l}-0.7176 \\
-1.60 \\
\end{array}$ & $\begin{array}{l}-1.5029 * \\
-2.10\end{array}$ & $\begin{array}{l}-0.3442 \\
-0.45 \\
\end{array}$ & $\begin{array}{c}110 \\
0.0552 \\
\end{array}$ \\
\hline R\&D expenditure & $\begin{array}{c}-0.9444 * * \\
-2.47\end{array}$ & $\begin{array}{l}-0.3826 \\
-0.69\end{array}$ & $\begin{array}{c}-0.7377 * * \\
-2.47\end{array}$ & $\begin{array}{c}283 \\
0.0656\end{array}$ \\
\hline
\end{tabular}




\begin{tabular}{|c|c|c|c|c|c|}
\hline & $\mathbf{N}$ & Mean & Median & Std. dev. & $\begin{array}{c}\text { Not relevant } \\
(\%)\end{array}$ \\
\hline \multicolumn{6}{|l|}{ Panel A: Full sample } \\
\hline Compensation design & 428 & 2.739 & 3 & 1.122 & $25.7 \%$ \\
\hline Dividend policy & 430 & 2.736 & 3 & 1.211 & $21.9 \%$ \\
\hline Capital structure & 430 & 2.797 & 3 & 1.149 & $17.4 \%$ \\
\hline Long-term investments & 430 & 2.887 & 3 & 1.181 & $17.4 \%$ \\
\hline Hiring / layoff decisions & 429 & 2.500 & 2 & 1.181 & $24.9 \%$ \\
\hline$R \& D$ expenditure & 427 & 2.430 & 2 & 1.182 & $28.6 \%$ \\
\hline Financial reporting & 431 & 3.159 & 3 & 1.121 & $14.2 \%$ \\
\hline Corporate Governance & 430 & 2.986 & 3 & 1.118 & $16.3 \%$ \\
\hline \multicolumn{6}{|l|}{ Required rate / Payback } \\
\hline period & 424 & 2.623 & 3 & 1.132 & $30.0 \%$ \\
\hline \multicolumn{6}{|l|}{ Panel B: Chairmen } \\
\hline Compensation design & 148 & 2.689 & 3 & 1.081 & $28.4 \%$ \\
\hline Dividend policy & 147 & 2.700 & 3 & 1.282 & $25.2 \%$ \\
\hline Capital structure & 147 & 2.838 & 3 & 1.217 & $20.4 \%$ \\
\hline Long-term investments & 147 & 2.809 & 3 & 1.283 & $21.8 \%$ \\
\hline Hiring / layoff decisions & 147 & 2.324 & 2 & 1.204 & $30.6 \%$ \\
\hline$R \& D$ expenditure & 147 & 2.450 & 2 & 1.201 & $32.0 \%$ \\
\hline Financial reporting & 149 & 3.098 & 3 & 1.174 & $18.1 \%$ \\
\hline Corporate Governance & 147 & 3.000 & 3 & 1.085 & $18.4 \%$ \\
\hline \multicolumn{6}{|l|}{ Required rate / Payback } \\
\hline period & 146 & 2.606 & 3 & 1.114 & $32.2 \%$ \\
\hline
\end{tabular}


TABLE 7. Short-term pressure and firm profitability

This table reports the results from regressing firm profitability, measured either through ROA (return on total assets, columns $A$ to $C$ ) or ROE (return on equity, columns $D$ to $F$ ) on our survey variable for the shortterm pressure (pressure, with values ranging from 1 to 5) and firm controls: In(total_assets), the logarithm of total assets, as a proxy for size; solidity, equity to total assets, as a firm level risk variable; and OWN_20, the percentage of equity owned by the largest owner, as proxy for the benefits of corporate control. Columns A reports the base-case using all observations that do not lack data points, Column B only for the non-financial firms, and Column $\mathrm{C}$ using only oneobservation per firm and the average firm level pressure measure. Columns D to F report the same models using ROE instead of ROA. All models are estimated using robust and clustered standard errors for observations from the same firm. T-values are provided below the parameter estimates. ${ }^{*}$ denotes significance at least at the $5 \%$ level, and ${ }^{* *}$ at the $1 \%$ level, one-sided tests.

\begin{tabular}{|c|c|c|c|c|c|c|}
\hline Model & Column A & Column B & Column C & Column D & Column E & Column F \\
\hline Dependent & & $\begin{array}{l}\text { ROA, } \\
\text { no }\end{array}$ & $\begin{array}{c}\text { ROA, using } \\
\text { average } \\
\text { pressure }\end{array}$ & & $\begin{array}{l}\text { ROE. } \\
\text { No }\end{array}$ & $\begin{array}{c}\text { ROE, using } \\
\text { average } \\
\text { pressure }\end{array}$ \\
\hline Variable & ROA & financials & & ROE & financials & \\
\hline \multirow[t]{2}{*}{ Pressure } & $-1.6205^{* *}$ & $-1.9005^{* *}$ & $-1.6094 *$ & $-3.2399 * *$ & $-3.7205^{* *}$ & $-3.4415^{* *}$ \\
\hline & -2.28 & -2.32 & -2.00 & -3.16 & -3.09 & -2.81 \\
\hline \multirow[t]{2}{*}{ In(total_assets) } & $2.0620 * *$ & $2.4695^{* *}$ & $1.9928^{* *}$ & $3.8035^{* *}$ & $4.0388^{* *}$ & $3.6459 * *$ \\
\hline & 4.99 & 5.15 & 5.02 & 5.72 & 5.20 & 5.73 \\
\hline \multirow[t]{2}{*}{ Solidity } & $0.1069 * *$ & 0.0444 & $0.1096 *$ & 0.0276 & -0.0232 & 0.0393 \\
\hline & 2.03 & 0.61 & 2.21 & 0.36 & -0.20 & 0.57 \\
\hline \multirow[t]{2}{*}{ OWN_20 } & $0.0936 * *$ & 0.0772 & $0.1009 * *$ & $0.1087^{*}$ & 0.1072 & $0.1093 *$ \\
\hline & 2.13 & 1.54 & 2.39 & 1.72 & 1.42 & 1.88 \\
\hline Obs (N) & 426 & 345 & 332 & 405 & 324 & 315 \\
\hline F-value & 12.09 & 14.78 & 11.56 & 12.15 & 10.65 & 12.62 \\
\hline $\mathbf{R}^{2}$ & 0.1388 & 0.1478 & 0.1212 & 0.1532 & 0.1511 & 0.1535 \\
\hline
\end{tabular}

